\title{
Solid pseudopapillary tumor of the pancreas: A case report
}

Hikmet Aktaş ${ }^{1}\left(\right.$ ID), Özgen Işık ${ }^{1}\left(\right.$ ID), Remzi Emiroğlu' ${ }^{1}($ ID)

${ }^{1}$ Clinic of General Surgery, Acibadem Bursa Hospital, Bursa, Turkey

\section{ABSTRACT}

Solid pseudopapillary tumor (SPT) of the pancreas is an uncommon pathological condition. It is classified as low-grade malignant neoplasm, but aggressive disease can be seen when the tumor size is larger than $5 \mathrm{~cm}$, microscopic malignant features and local invasion are present. Resection of the mass with clear margins is the procedure of choice. However, lymph node dissection may be necessary in large tumors.

Keywords: Pancreas, pseudopapillary tumor, malignancy

Cite this article as: Aktaş H, Işık Ö, Emiroğlu R. Solid pseudopapillary tumor of the pancreas: A case report. Turk J Surg 2020; 36 (1): 110-112

\section{Corresponding Author}

Özgen Işık

E-mail: ozgen006@yahoo.com

Received: 15.06 .2015

Accepted: 20.08.2015

Available Online Date: 18.03 .2020

@ Copyright 2020 by Turkish Surgical Society Available online at www.turkjsurg.com

DOI: $10.5578 /$ turkjsurg.3237

\section{INTRODUCTION}

Solid pseudopapillary tumor of the pancreas (SPT) is a rare entity commonly seen in young women (1). Only 1 to $2 \%$ of all pancreatic neoplasms are consisted of SPTS $(1,2)$. Although it was classified as an epithelial low-grade malignant neoplasm by World Health Organization in 2010, there are several cases reported in the literature with malignant metastatic features (1-3). Complete surgical resection is the preferred treatment option for SPT of the pancreas.

This study aimed to present a young woman who underwent distal pancreatectomy and splenectomy for SPT of the pancreatic tail.

\section{CASE REPORT}

A 41-year-old woman with a mass located at the pancreas tail that was detected on routine abdominal ultrasonography was admitted to the outpatient clinic. Abdominal CT scan showed a solid mass of $10 \mathrm{~cm}$ in diameter (Figure 1a). Tumor marker (carcinoembriogenic antigen and Ca 19.9) levels were in normal range. There was not an evidence of distant metastasis in preoperative imaging studies of the abdomen and thorax. The patient underwent open distal pancreatectomy and splenectomy on October 10, 2014 (Figure 1b). Postoperative recovery was uneventful, and the patient was discharged on postoperative day 4.
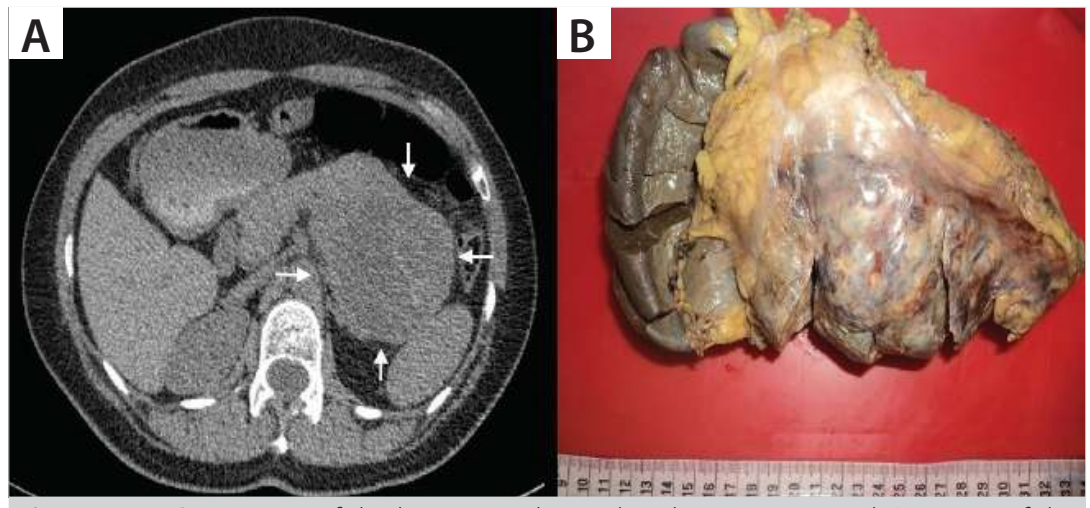

Figure 1. A. CT imaging of the huge mass located at the pancreatic tail, B. Image of the en-bloc resected specimen from the posterior aspect. 
Pathological examination of the specimen revealed SPT of the pancreatic tail with low mitotic activity. Surgical margins were clear, and none of the 21 lymph nodes were metastatic. A decision was made to proceed with a 3-month follow-up interval during the first year of surgery. The patient was doing well with no evidence of recurrence or distant metastasis during the routine office visit on postoperative month 6 . An informed consent was obtained from the patient presented in this report.

\section{DISCUSSION}

Solid pseudopapillary tumor of the pancreas is an uncommon pancreatic mass, and its origin is still debatable (2). Most data on this tumor consists case reports and small case series. During the past few years, several studies investigating the natural history and malignant potential of SPT were published $(1,2)$.

Solid pseudopapillary tumors of the pancreas are seen as encapsulated masses with well-defined borders including both solid and cystic components in CT scan. MRI may provide more detailed information about tissue characteristics such as hemorrhage, cystic degeneration, and necrosis (4). Differential diagnosis of SPT includes pancreatic pseudocysts, endocrine neoplasms, pancreatoblastoma, and acinar cell carcinoma (5).

Perineural and vascular invasion, invasion of the surrounding tissues, tumor diameter larger than $5 \mathrm{~cm}$ have been reported to be associated with increased malignant potential (1). Additionally, tumor size larger than $8 \mathrm{~cm}$, presence of microscopic poor prognostic factors, and stage IV disease (distant metastasis or peritoneal implants) have been determined as predictive factors of recurrence (2). SPT has been reported to metastasize to the peritoneum, liver, and lymph nodes. Formal lymph node dissection in addition to the resection of the tumor is recommended for patients with large tumors (1). In our patient, the only risk factor of poor prognosis was the tumor size.

Resection of the mass with clear margins is the procedure of choice for SPT. Distal pancreatectomy with or without splenectomy is enough for the management of the lesions located at the pancreatic tail. Laparoscopic spleen preserving resection for distal pancreatic tumors may be feasible when the tumor size is small (6). Minimally invasive laparoscopic resection for pseudopapillary tumor of the pancreas offers better short-term benefits than open surgery, such as shorter length of hospital stay and earlier toleration of the oral diet with comparable morbidity rates and long-term outcomes (5). Unfortunately, laparoscopic technique could not be utilized and preservation of the spleen was not feasible in this case due to the huge size of the mass.

Since it is a low-grade malignancy and surgical resection of the tumor is the only curative option, data regarding the impact of adjuvant chemotherapy on the outcomes are limited and con- troversial. However, systemic multimodal treatment may benefit when metastatic disease is present (7).

\section{CONCLUSION}

Solid pseudopapillary tumor of the pancreas may be in aggressive behavior when the tumor size is large, microscopic malignant features and local deep invasion exist. Resection of the tumor with clear margins, and lymph node dissection for tumors larger than $5 \mathrm{~cm}$ seems to be the best surgical strategy in the management of SPT's. Post-operative follow-up strategy should be personalized based on the presence of risk factors. Routine imaging of the abdomen during follow-up may be helpful in patients with aggressive tumors.

Informed Consent: Written informed consent was obtained from patient who participated in this case.

Peer-review: Externally peer-reviewed.

Author Contributions: Concept - R.E.; Design - R.E.; Supervision - R.E.; Resource - R.E.; Materials - H.A., Ö.I, R.E.; Data Collection and/or Processing H.A., Ö.I; Analysis and/or Interpretation - H.A., Ö..; Literature Search - H.A., Ö.ı; Writing Manuscript - H.A., Ö.l.; Critical Reviews - R.E.

Conflict of Interest: No conflict of interest was declared by the authors.

Financial Disclosure: The authors declared that this study has received no financial support.

\section{REFERENCES}

1. Kim M, Choi D, Choi S, Heo J, Sung J. Surgical treatment of solid pseudopapillary neoplasms of the pancreas and risk factors for malignancy. Br J Surg 2014;101:1266-71. [CrossRef]

2. Kang CM, Choi SH, Kim SC, Lee WJ, Choi DW, Kim SW, et al. Predicting recurrence of pancreatic solid pseudopapillary tumors after surgical resection: a multicenter analysis in Korea. Ann Surg 2014;260:348-55. [CrossRef]

3. Bosman FT, Carneiro F, Hruban RH, Theise ND. WHO classification of tumours of the digestive system. World Health Organization; 2010. [CrossRef]

4. Yagci A, Yakan S, Coskun A, Erkan N, Yildirim M, Yalcin E, et al. Diagnosis and treatment of solid pseudopapillary tumor of the pancreas: experience of one single institution from Turkey. World J Surg Oncol 2013;11:308. [CrossRef]

5. Zhang R, Yan J, Xu X, Chen K, Ajoodhea H, Mou Y. Laparoscopic vs open distal pancreatectomy for solid pseudopapillary tumor of the pancreas. World J Gastroenterol 2013;19:6272. [CrossRef]

6. Topgül K, Yürüker SS, Koca B, Kesicioğlu T. Spleen-preserving laparoscopic distal pancreatectomy: Two cases and review of the technique. Ulus Cerrahi Derg 2013;29:139-43. [CrossRef]

7. Tajima H, Takamura H, Kitagawa H, Nakayama A, Shoji M, Watanabe T, et al. Multiple liver metastases of pancreatic solid pseudopapillary tumor treated with resection following chemotherapy and transcatheter arterial embolization: A case report. Oncol Lett 2015;9:1733-8. [CrossRef] 


\section{OLGU SUNUMU-ÖZET}

Turk J Surg 2020; 36 (1): 110-112

\section{Pankreasın solid psödopapiller tümörü: Bir olgu sunumu}

Hikmet Aktaş ${ }^{1}$ Özgen Işık ${ }^{1}$, Remzi Emiroğlu ${ }^{1}$

'Acıbadem Bursa Hastanesi, Genel Cerrahi Kliniği, Bursa, Türkiye

\section{ÖZET}

Pankreasın solid psödopapiller tümörü (SPT) nadir görülen bir patolojidir. Düşük malignite potansiyeli bulunan bir neoplazm olarak sınıflandırılır, fakat tümör çapı 5 cm'den büyükse, mikroskobik malignite özellikleri mevcutsa ve lokal invazyon varsa hastalık agresif seyredebilir. Kütlenin güvenli cerrahi sınırlar ile rezeksiyonu tercih edilen prosedürdür. Ancak büyük tümörlerde lenf nodu diseksiyonu gerekebilir.

Anahtar Kelimeler: Pankreas, psödopapiller tümör, malignite

Doi: $10.5578 /$ turkjsurg.3237 